\title{
Insulation Breakdown Characteristics of Inverter Surge Resistant Enameled Wire Prepared with Organic/ Inorganic Hybrid Nanocomposite
}

\author{
Jae-Jun Park ${ }^{\dagger}$ and Seong-Sik Shin \\ Department of Electrical and Electronic Engineering, Joongbu University, Goyang 412-480, Korea \\ Jae-Young Lee \\ Hydrogen Fuel Cell Parts and Applied Technology Regional Innovation Center, Woosuk University, Wanju 565-902, Korea
}

\author{
Se-Won Han and Dong-Pil Kang \\ The Korea Electrotechnology Research Institute, Changwon 642-120, Korea
}

Received July 9, 2015; Revised July 16, 2015; Accepted July 16, 2015

\begin{abstract}
Insulation breakdown characteristics of an inverter surge resistant enameled wire were investigated in a twisted pair prepared with organic/inorganic hybrid nanocomposite. Organic polymer was polyesterimide-polyamideimide (EI/ AI) and inorganic material was a nano-sized silica. The enamel thickness was $50 \mu \mathrm{m}$ and the diameters of enameled copper wires were $0.75,1.024$, and $1.09 \mathrm{~mm}$, respectively. There were many air gaps in a twisted pair. Therefore, when the voltage was applied to the twisted pair, enamel erosion took place in the air gap area because of partial discharge according to Paschen's law. The insulation lifetime of the hybrid wire (HW) was 41,750 sec, which was 515.4 times more than the $81 \mathrm{sec}$ of EI/AIW. In addition, the shape parameter of HW was 2.58, which was 3.4 times higher than 0.75 of EI/AIW.
\end{abstract}

Keywords: Enamel insulated wire, Partial discharge, Insulation lifetime, Insulation breakdown voltage

\section{INTRODUCTION}

As environmental issues have attracted much interest at an international, national and local level in recent years, energy efficiency issues have become important. In the industrial motor area, an increasing number of motors now have inverters or adjustable-speed drives to deliver the higher efficiency required for today's industrial motors. In addition, inverter power supplies that apply a pulse modulated (PWM) technique, in which

${ }^{\dagger}$ Author to whom all correspondence should be addressed:

E-mail: jjpark@jbm.ac.kr

Copyright $(2015$ KIEEME. All rights reserved.

This is an open-access article distributed under the terms of the Creative Commons Attribution Non-Commercial License (http://creativecommons.org/licenses/by-nc/3.0) which permits unrestricted
distribution, and reproduction in any medium, provided the original work is properly cited. insulated gate bipolar transistors (IGBTs) are used as a highspeed switching device, can improve the controllability of the motor torque and reduce the switching loss [1-3]. Furthemore, studies have shown that partial discharge (PD) is a key factor in the mechanism of the insulation breakdown due to the inverter surge [3-5]. Generally, PD characteristics have been studied in a twisted-pair with a polymeric insulator enameled wire. When the voltage was applied to a twisted pair, enamel film erosion takes place in an air gap area because of partial discharge according to Paschen's law $[4,5]$.

Where $\mathrm{V}$ is the breakdown voltage in volts, $\mathrm{p}$ is the pressure in atm or bar, and $d$ is the gap distance in meters. The constants a and $b$ depend upon the composition of the gas. For air at a standard atmospheric pressure of $101 \mathrm{kPa}, \mathrm{a}=4.36 \times 10^{7} \mathrm{~V} /(\mathrm{atm} \cdot \mathrm{m})$ and $b=12.8$ and the graph of this equation is the Paschen curve. Therefore, many researchers have also studied the effect of high- 
speed pulse waves with short-term rise on the insulation breakdown voltage [6-8]

Polyesterimide-polyamideimide enameled wire (EI/AIW) has good thermal and electrical insulation properties. Polyamide is a sort of polymer that has high insulation breakdown strength with good heat resistance, mechanical strength and chemical resistance. Therefore, polyamide insulated wires are used in harsh environmental conditions [9-11]. Polyimides are used in inverter-fed motor windings and high pressure coils for electric translators. In recent years, elements allowing high-speed switching, such as insulated-gate bipolar transistors (IGBTs), have been developed as inverter power devices.

In this study, insulation lifetime and insulation breakdown voltage were investigated in a twisted pair with polyesterimidepolyamideimide enameled round wires (EI/AIW) or EI/AI/nanosized silica hybrid enameled round wires (HW). The enamel thickness was $50 \mu \mathrm{m}$ and the diameters of enameled copper wires were $0.75,1.024$ and $1.09 \mathrm{~mm}$, respectively.

\section{EXPERIMENTS}

EI/AIW or HW was prepared by coating a round copper wire with polyesterimide-polyamideimide enamel or EI/AI/nanosized silica hybrid enamel, respectively (Sam Dong Co., Ltd., Korea). The enamel thickness was $50 \mu \mathrm{m}$ and the diameters of enameled copper wires were $0.75,1.024$ and $1.09 \mathrm{~mm}$, respectively. Therefore, the copper diameter became $0.745,1.014$ and $1.08 \mathrm{~mm}$, respectively.

All twisted pairs were prepared by twisting a couple of two straight lines of $125 \mathrm{~mm}$ under constant $1.4 \mathrm{~N} \cdot \mathrm{m}$ torque using a twisting machine. The number of the twisted turns used to determine the copper wire diameters of $0.75,1.024$ and $1.09 \mathrm{~mm}$ was 16,16 and 15 , respectively.

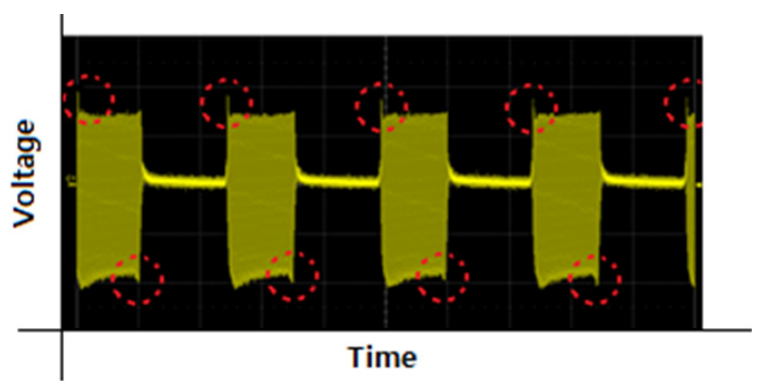

Fig. 1. Inverter surge waveform voltage at motor terminal.

In order to study insulation lifetime and insulation breakdown voltage, an inverter surge waveform voltage was applied to a sample as shown in Figure 1, where inverter surge peaks were marked with dotted circles. In order to apply $0 \sim 12 \mathrm{kV}$ with 50 1,000 Hz to twisted pairs, a withstanding voltage tester (Model : APCP-12 kV-100, Sky Innotek Co., Ltd.) for frequency acceleration was used. In order to apply high voltage to a twisted pair, an enamel insulation layer was removed from one side of the twisted pair and the other side remained without eliminating the enamel insulation layer. Subsequently, the specimen was arranged to the withstanding voltage tester. The insulation lifetime was then carried out at a speed of $40 \mathrm{~V} / \mathrm{s}$ until $6.25 \mathrm{kV}$ and it was maintained at $6.25 \mathrm{kV}$ until electrical insulation breakdown took place. The electrical breakdown voltage was also carried out at a rising speed of $40 \mathrm{~V} / \mathrm{s}$ until electrical breakdown took place.

\section{RESULTS AND DISCUSSION}

Figure 2 shows Weibull statistical analysis (Weibull++ 7.0) for the insulation lifetime of $(\bullet)$ EI/AIW and $(\bullet)$ HW twisted pairs at $6.25 \mathrm{kV}$ with $60 \mathrm{~Hz}$. The coil diameter of EI/AIW was $1.09 \mathrm{~mm}$ and that of HW was $1.024 \mathrm{~mm}$. The scale and shape parameters, and B10 value were obtained from the Weibull plots and listed in Table 1.

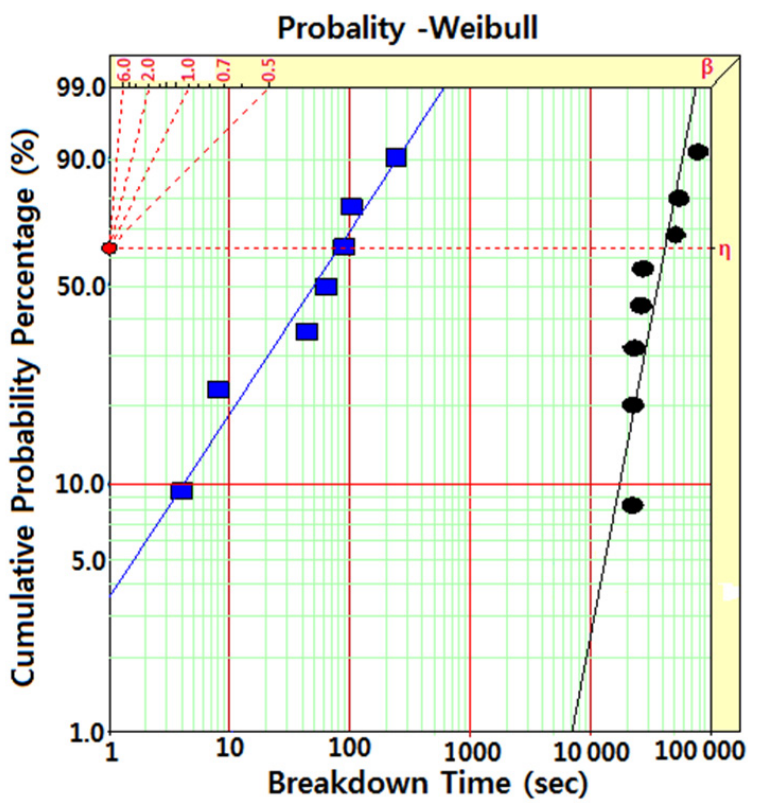

Fig. 2. Weibull statistical analysis of the insulation lifetime of (घ) EI/ AIW and $(\bullet) \mathrm{HW}$ twisted pairs at $6.25 \mathrm{kV}$ with $60 \mathrm{~Hz}$. Coil diameter of EI/AIW was $1.09 \mathrm{~mm}$ and that of HW was $1.024 \mathrm{~mm}$.

Table 1. Weibull parameters for the insulation lifetime of EI/AIW and HW twisted pairs obtained from Figure 2.

\begin{tabular}{cccc}
\hline System & $\begin{array}{c}\text { Scale Parameter } \\
(\mathrm{sec})\end{array}$ & $\begin{array}{c}\text { B10 Value } \\
(\mathrm{sec})\end{array}$ & $\begin{array}{c}\text { Shape } \\
\text { Parameter }\end{array}$ \\
\hline \hline EI/AIW & 81 & 4.3 & 0.75 \\
\hline HW & 41,750 & 17,952 & 2.58 \\
\hline
\end{tabular}

That is to say, the scale parameter represented the AC electrical breakdown strength by which $63.2 \%$ of the cumulative probability was expected to fail and the shape parameter could be obtained from the slope in other words, the data distribution. In addition, the $\mathrm{B} 10$ value referred to the electrical lifetime at which $10 \%$ would fail ( $90 \%$ would survive) under a given test condition [12]. The scale parameter of HW was $41,750 \mathrm{sec}$, which was 515.4 times higher than the $81 \mathrm{sec}$ of EI/AIW. The shape parameter of HW was 2.58, which was 3.4 times higher than the 0.75 of EI/ AIW,. These results meant nano-sized silica was evenly dispersed in EI/AI and provided an excellent AC insulation lifetime characteristic to EI/AI. Since the slope of the Weibull plot for EI/AIW was gentle and that of HW was very steep, the B10 value of HW was 4,175 times higher than that of EI/AIW, where the B10 value meant the safety factor of an insulation material.

Figure 3 shows the effect of coil diameter on Weibull statistical analysis of the insulation lifetime of HW twisted pairs with different coil diameters: $(\bullet)$ was $0.75 \mathrm{~mm}$ and $(\bullet)$ was $1.024 \mathrm{~mm}$, and the AC frequency was at $6.25 \mathrm{kV}$ with $60 \mathrm{~Hz}$. In addition, the Weibull parameters were listed in Table 2 . The scale parameter for $1.024 \mathrm{~mm}$ was $41,750 \mathrm{sec}$, which was 3.2 times higher than 


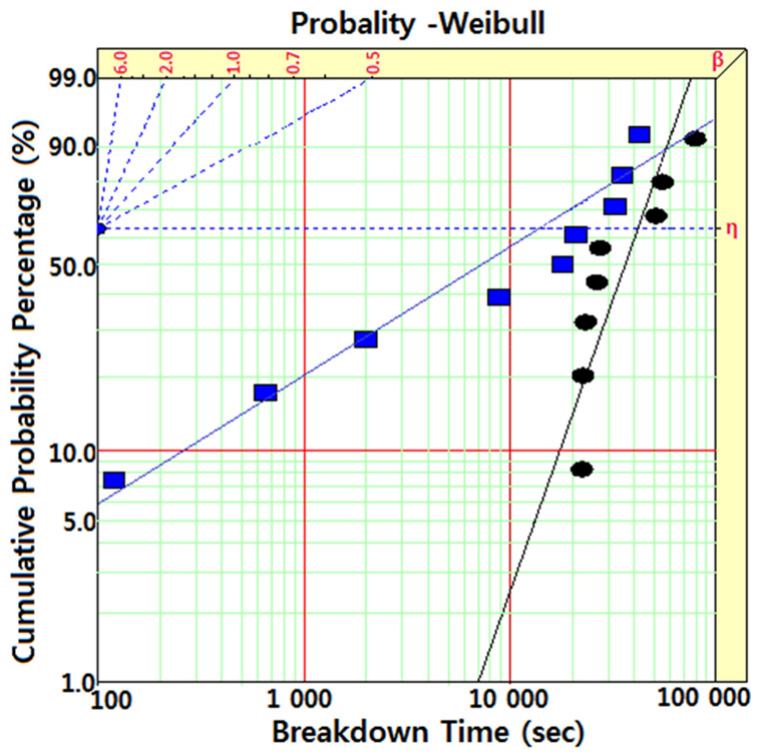

Fig. 3. Weibull statistical analysis for the insulation lifetime of HW twisted pairs at $6.25 \mathrm{kV}$ with $60 \mathrm{~Hz}$. Coil diameters were (₫) $0.75 \mathrm{~mm}$ and $(\bullet) 1.024 \mathrm{~mm}$.

Table 2. Weibull parameters for the insulation lifetime of HW twisted pairs at $60 \mathrm{~Hz}$. Coil diameters obtained from Figure 3.

\begin{tabular}{cccc}
\hline $\begin{array}{c}\text { Coil Diameter } \\
(\mathrm{mm})\end{array}$ & $\begin{array}{c}\text { Scale Parameter } \\
(\mathrm{sec})\end{array}$ & $\begin{array}{c}\text { B10 Value } \\
(\mathrm{sec})\end{array}$ & $\begin{array}{c}\text { Shape } \\
\text { Parameter }\end{array}$ \\
\hline \hline 0.75 & 13,039 & 251 & 0.78 \\
\hline 1.024 & 41,750 & 17,952 & 2.58 \\
\hline
\end{tabular}

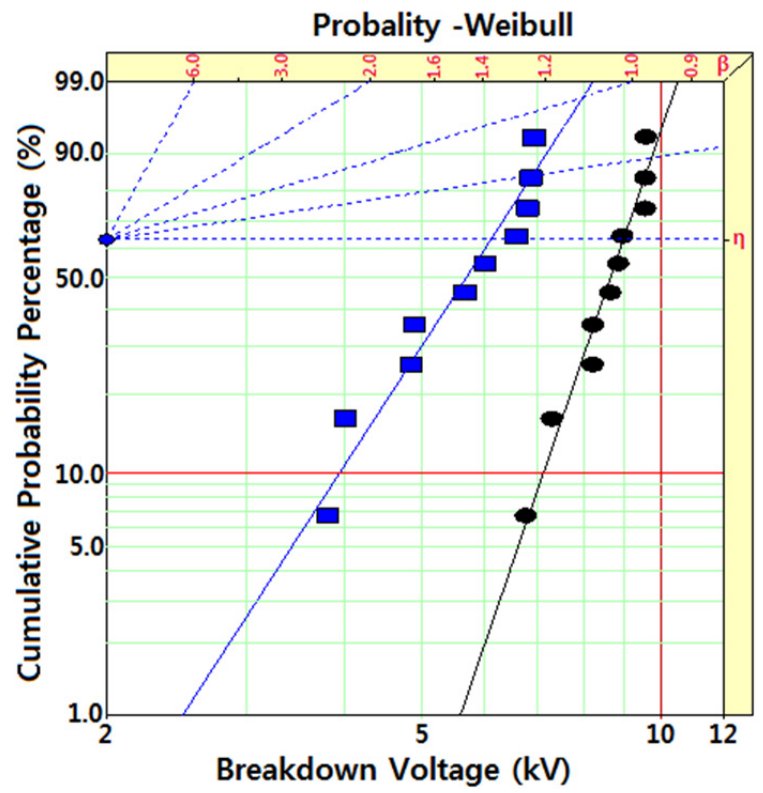

Fig. 4. Weibull statistical analysis for insulation breakdown voltage of HW twisted pairs at $(\bullet) 60 \mathrm{~Hz}$ and (•) 1,000 Hz. Coil diameter was 0.75 mm.

the $13,039 \mathrm{sec}$ of $0.75 \mathrm{~mm}$. In general, it is well known that air gap distance and temperature affect enamel erosion. As the diameter of the enameled copper wire increased, the air gap distance increased. Therefore, according to Paschen's law $[4,5]$ electrical
Table 3. Weibull parameters for the insulation breakdown voltage of HW twisted pairs at $(\bullet) 60 \mathrm{~Hz}$ and $(\bullet) 1,000 \mathrm{~Hz}$ obtained from Figure 4 . Coil diameter was $0.75 \mathrm{~mm}$.

\begin{tabular}{cccc}
\hline $\begin{array}{c}\text { Frequency } \\
(\mathrm{Hz})\end{array}$ & $\begin{array}{c}\text { Scale Parameter } \\
(\mathrm{kV})\end{array}$ & $\begin{array}{c}\text { B10 Value } \\
(\mathrm{kV})\end{array}$ & $\begin{array}{c}\text { Shape } \\
\text { Parameter }\end{array}$ \\
\hline \hline 60 & 8.97 & 7.12 & 9.7 \\
\hline 1,000 & 6.12 & 3.97 & 5.1 \\
\hline \hline
\end{tabular}

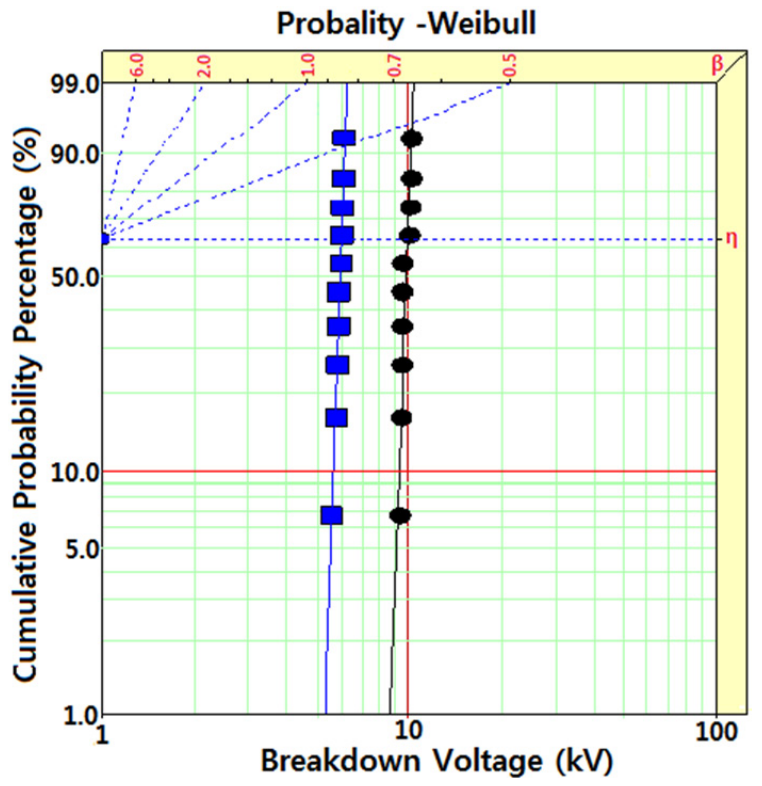

Fig. 5. Weibull statistical analysis for the insulation breakdown voltage of $\mathrm{HW}$ twisted pairs at $(\bullet) 60 \mathrm{~Hz}$ and $(\bullet) 1,000 \mathrm{~Hz}$. Coil diameter was $1.024 \mathrm{~mm}$.

Table 4. Weibull parameters for the insulation breakdown voltage of HW twisted pairs at $(\bullet) 60 \mathrm{~Hz}$ and $(\bullet)$ 1,000 Hz obtained from Figure 5 . Coil diameter was $1.024 \mathrm{~mm}$.

\begin{tabular}{cccc}
\hline $\begin{array}{c}\text { Frequency } \\
(\mathrm{Hz})\end{array}$ & $\begin{array}{c}\text { Scale Parameter } \\
(\mathrm{kV})\end{array}$ & $\begin{array}{c}\text { B10 Value } \\
(\mathrm{kV})\end{array}$ & $\begin{array}{c}\text { Shape } \\
\text { Parameter }\end{array}$ \\
\hline \hline 60 & 9.94 & 9.23 & 33.6 \\
\hline 1,000 & 6.00 & 5.67 & 38.1 \\
\hline
\end{tabular}

breakdown voltage steeply decreased until a low air gap distance and then increased gradually after the air gap distance. Moreover, as the diameter of the enameled copper wire increased, the temperature between the wires decreased. Therefore, the enamel erosion rate was low in the large diameter. The shape parameter of $1.024 \mathrm{~mm}$ was 2.58 , which was 3.3 times higher than the 0.78 of $0.75 \mathrm{~mm}$.

Figure 4 shows Weibull statistical analysis of the insulation breakdown voltage for HW with a coil diameter of $0.75 \mathrm{~mm}$ in a twisted pair form at $60 \mathrm{~Hz}$. The shape and scale parameters were obtained from the Weibull plots and listed in Table 3. The insulation breakdown voltage value at $60 \mathrm{~Hz}$ was $8.97 \mathrm{kV}$, which was 1.5 times higher than the $6.12 \mathrm{Kv}$ at 1,000 Hz. Furthermore, the B10 value at $60 \mathrm{~Hz}$ was $7.12 \mathrm{kV}$, which was 1.8 times higher than the 3.97 at 1,000 $\mathrm{Hz}$. In addition, the shape parameter at $60 \mathrm{~Hz}$ was 9.7, which was 1.9 times higher than the 5.1 at $1,000 \mathrm{~Hz}$.

Figure 5 shows Weibull statistical analysis of the insulation breakdown voltage for HW with a coil diameter of $1.024 \mathrm{~mm}$ in a twisted pair form at $1,000 \mathrm{~Hz}$. The shape and scale parameters 
were obtained from the Weibull plots and listed in Table 4 . The insulation breakdown voltage value at $60 \mathrm{~Hz}$ was $9.94 \mathrm{kV}$, which was 1.7 times higher than the $6.00 \mathrm{kV}$ at 1,000 $\mathrm{Hz}$. In addition, the $\mathrm{B} 10$ value at $60 \mathrm{~Hz}$ was $9.23 \mathrm{kV}$, which was 1.6 times higher than the 5.67 at 1,000 $\mathrm{Hz}$. In addition, the shape parameter at $60 \mathrm{~Hz}$ was 33.6, which was 0.9 times higher than that at $1,000 \mathrm{~Hz}, 38.1$.

\section{CONCLUSIONS}

Insulation breakdown characteristics of an inverter surge resistant enameled wire were investigated in a twisted pair prepared with organic/inorganic hybrid nanocomposite. The organic polymer was polyesterimide-polyamideimide (EI/AI) and the inorganic material was a nano-sized silica.

The insulation lifetime of the hybrid wire was $41,750 \mathrm{sec}$, which was 515.4 times higher value than the $81 \mathrm{sec}$ of EI/AIW. In addition, the shape parameter of HW was 2.58, which was 3.4 times higher than the 0.75 of EI/AIW. These results meant nanosized silica was evenly dispersed in EI/AI and provided an excellent AC insulation lifetime characteristic to EI/AI. The insulation lifetime for $1.024 \mathrm{~mm}$ of the coil diameter was 3.2 times higher than that for the $0.75 \mathrm{~mm}$ of the coil diameter. This meant that the enamel erosion rate was lowered in the sample of larger coil diameter. This was because air gap size and temperature affected the enamel erosion according to Paschen's law. The insulation breakdown voltage for HW with a coil diameter of $0.75 \mathrm{~mm}$ at 60 $\mathrm{Hz}$ was 1.5 times higher than that value at 1,000 $\mathrm{Hz}$.

\section{ACKNOWLEDGMENTS}

This work was financially supported by a grant (20131020000130) from the Ministry of Trade, Industry and Energy (MOTIE), Korea in 2014. It was also supported by Joongbu University in 2014.

\section{REFERENCES}

[1] H. Okubo, N. Hayakawa, and G. C. Montanari, IEEE Trans. Dielectr. Electr. Insul., 14, 1516 (2007). [DOI: http://dx.doi. org/10.1109/TDEI.2007.4401236]

[2] H. Kikuchi and H. Hanawa, IEEE Trans. Dielectr. Electr. Insul., 19, 99 (2012). [DOI: http://dx.doi.org/10.1109/TDEI.2012.6148507]

[3] Y. Kikuchi, T. Murata, Y. Uozumi, N. Fukumoto, M. Nagata, Y. Wakimoto, and T. Yoshimitsu, IEEE Trans. Dielectr. Electr. Insul., 15, 1617 (2008). [DOI: http://dx.doi.org/10.1109/ TDEI.2008.4712665]

[4] M. Kaufhold, G. Borner, M. Eberhardt, and J. Speck, IEEE Electr. Insul. Mag., 12, 9 (1996). [DOI: http://dx.doi. org/10.1109/57.537190]

[5] M. Kaufhold, H. Auinger, M. Berth, J. Speck, and M. Eberhardt, IEEE Trans. Industr. Electronics, 2, 396 (2000). [DOI: http:// dx.doi.org/10.1109/41.836355]

[6] S. R Chalise, S. Grzybowski, and C. D. Taylor, Proceeding of IEEE Electrical Ship Technologies Symposium (Baltimore, USA, 2009) p. 533.

[7] S. Grzybowski, E. A. Feilat, and P. Knight, Proceeding of the 12th International Symponium on High Voltage Engineering (Bangalore, India, 2001) p. 521.

[8] N. Hayakawa and H. Okubo, IEEE Electrical Insulation Magazine, 24, 22 (2008). [DOI: http://dx.doi.org/10.1109/ MEI.2008.4473051]

[9] E. Ildstad and S. R. Chalise, Annual Report Conference on Electrical Insulation and Dielectric Phenomena, p. 85 (2009). [DOI: http://dx.doi.org/10.1109/ CEIDP.2009.5377720]

[10] G. C. Stone, I. Culbert, E. A. Boulter, and H. Dhirani, IEEE Press Series on Power Engineering (2004).

[11] E. Sugimoto, IEEE Electrical Insulation Magazine, 5, 15 (1989). [DOI: http://dx.doi.org/10.1109/57.16949]

[12] J. J. Park, Y. B. Park, and J. Y. Lee, Trans. Electr. Electron. Mater., 12, 93 (2011). [DOI: http://dx.doi.org/10.4313/ TEEM.2011.12.3.93] 